\title{
Method of Designing and Implementing Outcome-Based Learning in Value Added Courses for Contemporary Skills which Enhances the Program Outcomes
}

\author{
Arun Kumar B.R \\ Dept. of Computer Applications \\ BMS Institute of technology and Management \\ Doddaballapura Main Road, Avalahalli, Yelahanka, Bengaluru-560064, Karnataka, India. \\ (Affiliated to Vivesvaraya Technological University, Belagavi) \\ arunkumarbr@bmsit.in
}

\begin{abstract}
The acceptance of outcome-based education (OBE) is increasing since the 1980s across different countries in the world. Implementation of OBE is essential right from primary education to postgraduate courses and even in research programs since the primary focus is on outcomes that are learner centric.
\end{abstract}

This paper analyses the OBE curriculum design, it reflects on the method of designing value-added courses (VAC) and its effectiveness. It is found that VACs are instrumental in reducing the curriculum gaps to attain program outcomes (POs) of any given curriculum along with targeted skills. This work demonstrates the curriculum gap analysis, determines sample of learners acquiring cognitive skills in randomly selected courses, presents a framework for Industry-endorsed open short-term courses, and introduces new formats for documenting VACs for project-based and case study-based learning. The VACs contribute to POs by nearly $20 \%$. It may be noted that VACs implementation enabled all POs attainment and gives no room for the curriculum gap. This paper contributes a comprehensive idea for offering several VACs that boost the achievement of POs at the expected level along with contemporary skills by considering a postgraduate degree.

\section{Arun Kumar B.R}

Dept. of Computer Applications

BMS Institute of technology and Management

Avalahalli, Yelahanka, Bengaluru-560064, Karnataka, India arunkumarbr@bmsit.in
Keywords: Course-Outcomes, Value-added courses, programme-outcomes, outcome-based education

\section{Introduction}

The biggest challenge of twenty-first-century education is students' engagement in the continuous learning process to acquire employability and or entrepreneurial skills. To face these challenges, the education system needs a proper framework such as outcome-based education (OBE) that results in effective learning. The frameworks of such practices were made across the countries by some reliable bodies without affecting the culture of learning in their native regions. National Board of Accreditation (NBA) in India is one such body that processes, defines parameters and criteria for accreditation that are in line with the best international practices. These practices oriented to assess the outcomes of the program. To achieve these outcomes, it is necessary to design an outcome-based curriculum that enables skills development. Inputs for defining the goals related to skill developments were provided by various stakeholders viz., industry, national policies, alumni, etc. Identified skills can be incorporated as course outcomes (COs) followed by the assessment, evaluation, and adaptation processes. In the context of ever-changing technological advancement, the curriculum needs periodical revisions with adoptions of innovative thoughts. This leads to meet the expectations of skills in contemporary areas which must help in revising the pedagogy in line with an effective OBE. In par with the skill development 
mission of India, youths of professional courses need to acquire skills that enable employment and entrepreneur opportunities. To provide competent professionals as per the demand, All India Council for Technical Education (AICTE) is working with an approach that is distinctive by way of a model curriculum for various disciplines. Few of the best approaches identified were self-learning content through MOOCs, training of technical teachers, student induction program, and mandatory internship for students, etc. As a part of OBE, the teachinglearning process (TLP) includes new methods such as virtual laboratories, design of experiments, developing concept applications are introduced through Information Communication Technology (ICT) platform. Some special features included in the curriculum were audit courses, open electives and dissertation.

An OBE curriculum design starts by identifying a set of courses in line with guidelines given by AICTE, UGC and any other statuary body concerning components, total no. of credits and other guidelines given by the parent universities to which an institution is affiliated. Skills of the course goals are determined by inputs of all stake holders and limited by time and resources. Each course syllabus contents maybe decided by having a discussion with different relevant stakeholders based on COs defined, followed by this, finalize the COs for each course, define module and unit objectives based on Blooms' Taxonomy, define assessment tools (test items) and instructional strategies which are also important. The design of an OBE curriculum need to consider the documents, processes, criteria and other expectations of NBA and Washington Accord. An OBE curriculum of Tier-II institutions may be designed using the following processes as shown in Figure 1.

In the case of Tier-II institutions, where POs attainment has to be achieved for the given syllabus, value-added courses (VACs) may also be considered for PO mapping. VACs or value add-ons are the ones that may play a significant role in bridging the gap by enhancing the learning and building competency. Any professional program is an edge to enter the industry/ real world to work in a particular field, it is recommended to enrich the syllabus/curriculum, TLP, assessment, and evaluation in the perspective of the domain is proposed. It is equally important to focus on acquiring non-domain skills.

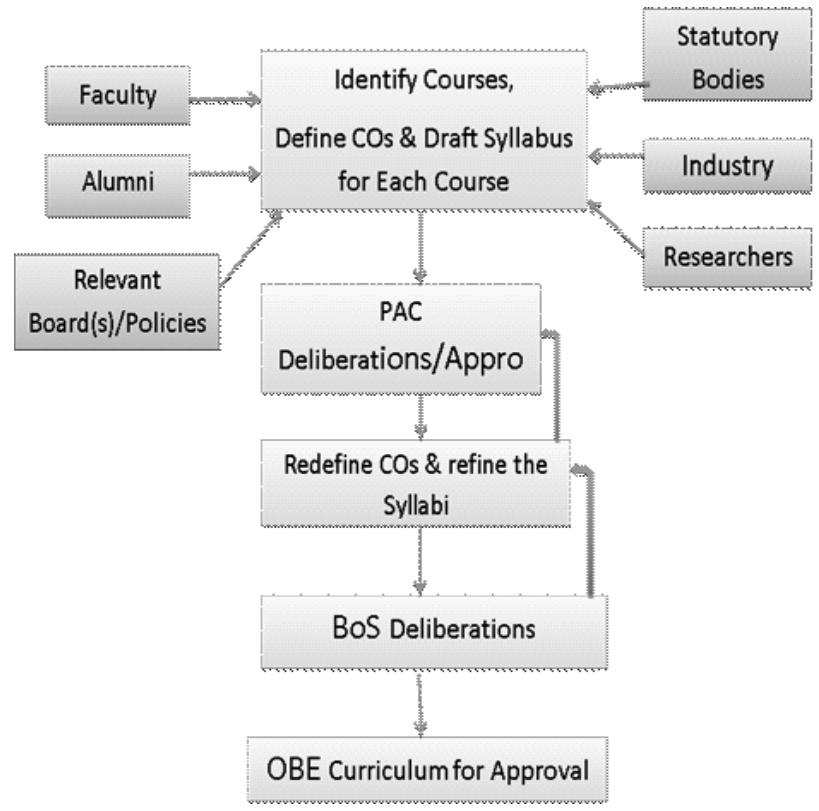

Fig. 1: Processes for designing OBE curriculum

In case of an affiliated system where the course coordinator is not able to decide the syllabus, he can add topics beyond the syllabus which are relevant for $\mathrm{CO}$ attainment and hence PO. In other words, the University syllabus is the only indication that gives you what is to be covered at the minimum. Whenever required, keeping University syllabus as a minimum standard, a set of value-added programs (VAP) may be added to reduce the gap but not overloading the students. It is a challenge to offer VAC for all students which are introduced in addition to the syllabus except motivating them. Every course is offered should be given an overview of the course objectives as a part highlighted rather than mentioning topics of the syllabus. In the case of VAC design, COs need to focus on specific skills required to achieve at the expected cognitive levels. It is a set of challenges a teacher has to address and mitigate them to successfully implement OBE. Therefore, teacher diplomatically, innovatively, contextually needs to adopt a customized methodology for implementation and get the learners achieve the desired skills.

Today, delivering content available in the text/reference book with a mere intention of the pouring of information does not encourage student engagement in learning. In the VAC syllabus, the links of the global/regional experts and the industries who directly or indirectly use the tools/ skillsets of the VAC Course may be included as a reference along with the textbooks, reference books, journals, and useful 
websites. Therefore, the content and mode of delivery need to be improved / innovative. Instructional strategies need to facilitate learning at higher Bloom's cognitive level to acquire both domain skills, interpersonal skills with an orientation towards application to industry, society, and environment. Conceive, design, implement, and operate (CDIO) an approach is a suitable approach for Project Courses preferably when academic project outcome is a deployable product. OBE curriculum design is a continuous process with the active participation of various stakeholders such as Industry, Alumni, Academia, and in line with norms/guidelines of statutory bodies including concerned board such as CSAB (Computer Science Accreditation Board). Curriculum gap, strategies to overcome them in terms of a set of VAC and course contents are to be deliberated in meeting such as Board of Studies (BoS) or Department Advisory Board (DAB) for finalization/approval. DAB may consist of members from different domains namely experts from Industry, Research, Alumni, Parents, Senior Students, and Senior/junior professors.

COs are foundation stones for the effective OBE approach, they must be designed with at most care based on the present needs, resources (internal and external), and the available framework of time. COs need to be achievable, specific, and measurable (Arun Kumar B.R, 2019). In practice, while defining COs, non-scalable terms, and abstractive words such as understand, know, learn, appreciate, and comprehend must be avoided. Set targets for learning outcomes start with the scalable term 'Apply' which avoids the practice of evaluation using the terms 'explain, describe, and another list of common terms which are in practice in the regular exam pattern. Further, with a higher cognitive level of COs, the teacher must know the limitations in the time frame and resources. For example, 'Design a sensor for measuring bacterial infection on a tooth' is measurable but not achievable for a six-month course because of the short time and limitations of resources. Therefore, $\mathrm{CO}$ defined has to be verified to know whether it is achievable, specifications are given, and measurable within the scope of the program.

After designing the COs, a teacher has to identify assessment tools/methods and use improved instruction methods. While demonstrating a concept use of real-world examples will enhance learning, especially if some activity is conducted in a team. There is a need for a resource platform where real- world problems are posted and discussed. It is very essential to focus on laboratories with hands-on real or virtual experiences the student can learn. Students can be given the task of exploring the kind of Block Box Experiment where the student needs to identify through learned basic skill sets. Laboratory assignment if focused on open-ended questions enables students to come up with multiple solutions and choose the optimal one. Concerning ICT usage, for example, while drawing the graph student may be asked to do using some new modern tools. While writing project reports, students can be asked to cite all relevant required references and manage them with the help of reference management tools. Future education and industry are driven by key disruptive forces such as globalization, changing demographics, and technological advancements. Students are to be prepared to face these challenges, build competencies to provide sustainable solutions, create and utilize the new opportunity which adds value to the society, environment, and industry. The industry environment is branded by high-performance work culture, intense competition, emphasis on quality and productivity, value addition, etc. In general, the industry is not ready to train graduates with these characteristics. Therefore, to meet the industry expectation, it is necessary to design and implement curriculum and instructional processes in collaboration with industry (Palomba, C., Banta, T. 1999).

To enable the students in this direction, it is the teacher who shows the path to learn contemporary knowledge, skills to be applied to new situations, analyse information based on the research literature, common sense, law perspectives, collaborate, solve problems, and make decisions. Facilitators implement important core competencies such as collaboration, digital literacy, critical thinking, problem-solving and self- learning (Palomba, C., Banta, T. 1999). Further, by applying different cognitive levels higher-order thinking skills can be implemented in learning.

Problem-based and technology-enhanced learning to improve engineering design competencies are also best practices that foster the attainment of POs with the required graduate skills (Palomba, C., Banta, T. 1999), (Elaine H.J.Yew, Karen Goh ,2016).

As the basis for life-long learning, "information literacy can be the core literacy of the twenty-first century, a kernel for all other literacies". To achieve this, an online game-based learning approach is 
introduced in (Abidin, Z., Anuar, A., Shuaib, N. H. 2009), (Elaine H.J.Yew, Karen Goh 2016). Researchbased teaching and learning is another strategy that can add value. This is because research and system of higher education can underpin the national development (Abidin, Z et al 2009), (Anderson, L. W., Krathwohl, D. R. (Eds.). 2001).

OBE the curriculum in its typical sense can motivate self-learning by individual and in a team. Curriculum and instructions are to be designed to meet the stated benchmark of achievements addressing all the types of learners. A literature study carried out revives that Tier-II institutions who offered VAC are not considered as a course with COs defined and direct assessment is done for PO attainment including the works mentioned in this article reference section.

In this paper, different best-practiced VACs that add values are narrated may be adopted along with ICT tools in different programs. This leads to better OBE curriculum design, instructional strategies, and assessment. It is organized into three sections. Section-1 presents a detailed description of outcomebased curriculum design, challenges to engage the learners, setting course goals, and initiatives of statutory bodies in India. In Section-2, different VACs are explained; a new framework for industryendorsed open short term course is introduced. Further, this section explained enhanced program attainment due to VACs. Finally, the paper offers its conclusion and recommends best-practiced VACs.

\section{Value Added Courses}

The general approach for identifying VACs to reduce the curriculum gap is depicted in Figure 2. The given syllabus is analysed by taking inputs from all stakeholders to find the curriculum gap. With the approval of the Program Assessment Committee (PAC) followed by Department Advisory Board (DAB), VACs are identified for implementation. PAC consists of Head of the department (HoD) as a chair, program coordinator, Module coordinator for the syllabus components as per NBA/ accreditation board. DAB consists of members from different domain namely: academia, industry, alumni, research, parents, students, program coordinator, and senior professor of the program.

Once the curriculum gap is identified, to address the gap following value add-ons with COs may be implemented in case of programs offered by Tier-II institutions. They are Expert Talks, MOOCs, partial delivery of classes for a specific course and evaluation by industry experts, VACs with specific skills focus Industrial lab establishment to partially/completely address contemporary topics and motivate the students, "Focused seminar series" by students which focuses on society /industry and environment issues Arun Kumar B.R (2019), Arun Kumar B.R (2018). Abidin, Z., Anuar, A., Shuaib, N. H. (2009). Virtual industry laboratories may be established online and its sessions may be conducted jointly with industry experts. Open-ended questions as an extension of regular laboratory experiments defined by the university will enable learners to attain higher cognitive skills. All the above schemes are to be designed around the COs defined. Students' performance is evaluated through proper assessment tools; PO attainments are calculated through COs attainment computation.

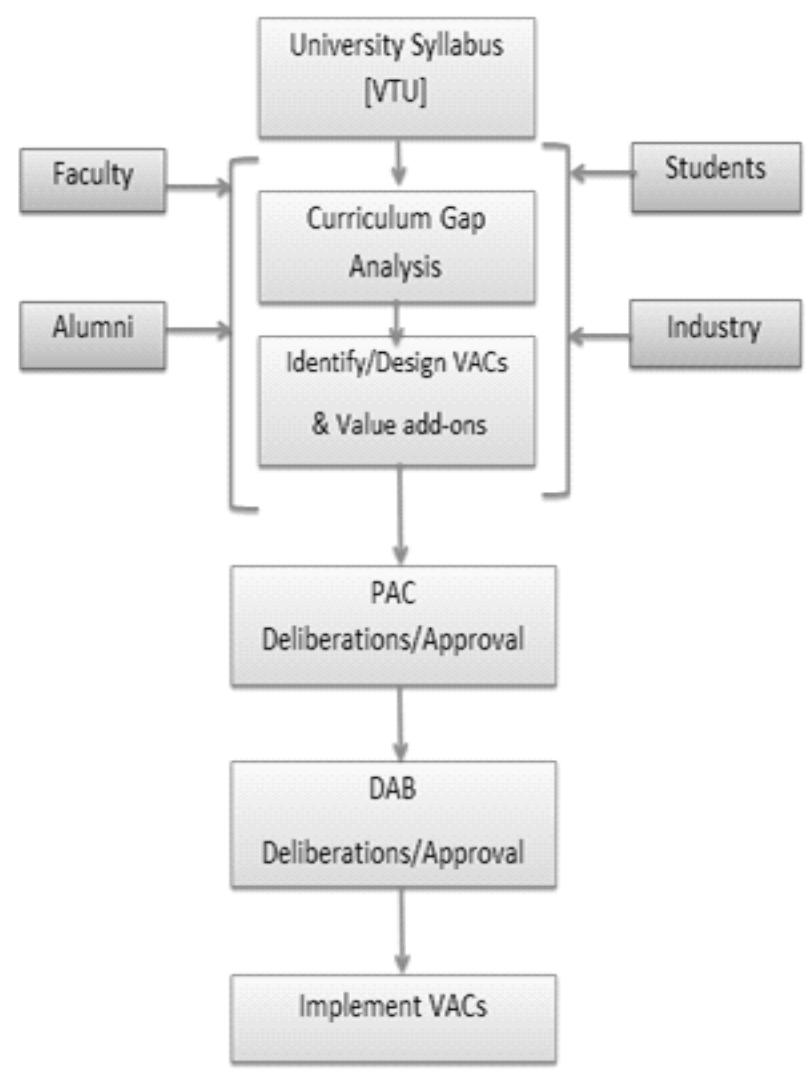

Fig. 2: Process for identifying VACs

POs were derived from NBA graduate attributes as per the SAR Jan. 2013 -old scheme of NBA for Master of Computer Applications program. The Table-1 represents the skills of the corresponding PO derived. In the next section, a new VAC is introduced. 
Table 1: Skills representing POs derived from NBA graduate attributes

\begin{tabular}{|c|c|}
\hline \multicolumn{2}{|c|}{$\begin{array}{c}\text { The graduates will have an ability to do the following with } \\
\text { respect to providing IT solutions at the time of graduation }\end{array}$} \\
\hline PO1 & Apply knowledge \\
\hline PO2 & Analyse / solve IT problems \\
\hline PO3 & Design, Develop / evaluate \\
\hline PO4 & Investigations of complex problems \\
\hline PO5 & Use techniques/ modern tools \\
\hline PO6 & Professional/Cyber ethics \\
\hline PO7 & Life-long learning \\
\hline PO8 & $\begin{array}{l}\text { Play different roles in multidisciplinary } \\
\text { environments }\end{array}$ \\
\hline PO9 & Communicate effectively \\
\hline PO10 & IT solutions for socio-environmental issues \\
\hline PO11 & Member/ leader in multidisciplinary teams. \\
\hline PO12 & Business opportunities/ value for the society \\
\hline
\end{tabular}

A. Industry endorsed Open Short-term Courses (IEOSC) for PBL/Mini-project

In addition to above listed VACs, Open Short Term Courses for mini-project which facilities enhanced learning with specific skills designed by course coordinator with the involvement of industry experts, Alumni working in the relevant area/domain and current students, is considered as a part of OBE. This course was kept open for all discipline students. This was offered to enable learners to get the ability to demonstrate insights of contemporary topics that are interdisciplinary, and the outcome can also be product development using the CDIO approach. In the framework shown below, an attempt is made to depict the industry involvement at various stages which includes partial delivery of classes. Since it is treated as a course, COs are written in discussion with all the concerned stakeholders including Industry, Syllabus, and problem statements are defined in line with COs and the same to be documented with necessary approval. Assessment and evaluation have to be done jointly done by Course Coordinator and industry experts who involved. Example COs defined for the Course of duration 40 hours are shown in Table-2.

Industry representatives participate in syllabus design and framing problems relevant to society, environment, and industry. Internal resource persons
Table 2: COs for the open short-term course IoT\& Cyber Security

\begin{tabular}{|l|c|}
\hline \multicolumn{1}{|c|}{ CO1: Demonstrate the fundamental } \\
$\begin{array}{l}\text { concepts of IoT \& Cyber Security for the } \\
\text { given problem. }\end{array}$ & PO1 \\
\hline $\begin{array}{l}\text { CO2: Analyse potential opportunities in } \\
\text { PO7 }\end{array}$ & PO1 \\
$\begin{array}{l}\text { IoT \& Cyber Security for societal and } \\
\text { environmental needs and formulate the } \\
\text { problems and list requirements. }\end{array}$ & PO2 \\
\hline $\begin{array}{l}\text { CO3: Design and implement IoT / } \\
\text { Cyber Security solutions to societal and } \\
\text { environmental problems by developing } \\
\text { products. }\end{array}$ & PO7 \\
\hline $\begin{array}{l}\text { CO4. Develop the solution by applying } \\
\text { appropriate techniques, software } \\
\text { engineering and management principles } \\
\text { and modern tools to meet the requirements } \\
\text { either as an individual or by involving in a } \\
\text { team. }\end{array}$ & PO7 \\
\hline $\begin{array}{l}\text { CO5. Verify \& validate the data and } \\
\text { results to arrive at valid conclusions and } \\
\text { communicate the work done effectively in } \\
\text { terms of presentations, writing reports and } \\
\text { research article as per the format given. }\end{array}$ & PO7 PO9 \\
\hline
\end{tabular}

are generally assigned responsibility to take the active role in consultation with Faculty Council, industry, alumni, and inputs from HOD including Town-hall with students. Internal resource persons who are Course coordinators are responsible to write COs, discuss and design the syllabus/problem statements for projects, get the endorsement from at least any two organizations working on this domain and maintain documents.

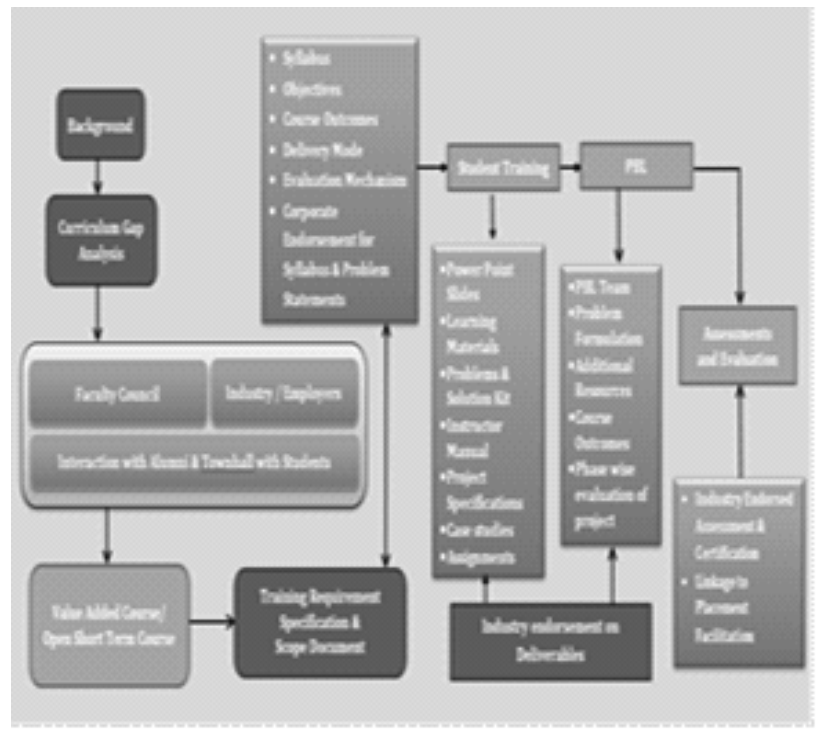

Fig. 2: Framework for designing an open short-term course endorsed by Industry experts 


\section{B. Project based Learning (PBL)}

To achieve a higher cognitive level of learning PBL can be introduced as a course or as an extension of the regular course with the following plan as shown in Table 3 .

Table 3 : Course Outcome with Attainment for computer Organization Course

\begin{tabular}{|c|c|c|c|}
\hline $\begin{array}{l}\text { Course } \\
\text { Code }\end{array}$ & 17MCA24 & Program & MCA \\
\hline $\begin{array}{c}\text { Course } \\
\text { Title }\end{array}$ & $\begin{array}{c}\text { Operating } \\
\text { Systems }\end{array}$ & Semester & 2nd \\
\hline $\begin{array}{c}\text { Faculty } \\
\text { Name }\end{array}$ & ABC & $\begin{array}{c}\text { Academic } \\
\text { Year }\end{array}$ & $\begin{array}{c}\text { 2017-18- } \\
\text { Even Semester }\end{array}$ \\
\hline
\end{tabular}

Objectives of Project Based Learning (PBL):

- To improve the ability to analyze the given problem, design solution, implement and to arrive at the valid conclusions.

- To motivate self-learning.

- To be able to map the concept to programming.

- To bring awareness on integrity

- To promote teamwork with members of different backgrounds

PBL COs: At the end of the course students will be able to:

- CO1: Analyse and formulate the given problem, identify the methodology for implementation and list possible outcomes (PO1, PO2, PO7).

- CO2: Design solution to solve the given problem in terms of the design of algorithms/implementation of mechanisms (PO1, PO2, PO7)

- CO3: Implement and analyze/test the results to arrive at the valid conclusions (PO3, PO7, PO9)

- CO4: Write effective reports to make quality presentations and work in a team (PO3, PO5, PO7, PO9, P011)

- CO5 : : Exhibit academic integrity and professional ethics followed during the project work (PO4, PO7, PO9)

Note:

1. Faculty/ student members have to discuss the selected problem and analyse its relevance in the context of the scope of competency enhancement with innovative ideas.

2. Project type may also be of intensive programming

3. A project report content can be 15 pages to be submitted along with plagiarism check report.

4. A faculty member to review the progress of the project at the end of every week.

5. The Good assignment can lead to the creation of innovative opportunity in industry/society and paper publication/patent.

6. Project complexity should be of 30 hours of work to 2 nd semester and 40 hours of work to 4 th-semester students.

7.Project synopsis and report are to checked in plagiarism check tool and maintain $90 \%$ uniqueness.

\section{Project Work}

Largely PBL is focused on the conceptual realization of a particular course in terms of project work whose complexity is less compared to Project Work. Project work is a course in the final year / 6th semester MCA where students work for the entire semester for 600 hours approximately. The project work integrated into the MCA curriculum of VTU has nearly $16 \%-25 \%$ weight out of the entire curriculum.

This course may be mapped to all program outcomes (Pos). It plays a very significant role in

Table 4: COs of Project Work Course

\begin{tabular}{|c|c|}
\hline Cos & POs \\
\hline $\begin{array}{l}\text { CO1: Review the existing literature } \\
\text { to identify and formulate the } \\
\text { problem in contemporary } \\
\text { technologies/ issues related to } \\
\text { society/environment which leads to } \\
\text { the development of IT solution. }\end{array}$ & $\begin{array}{l}\text { PO1, PO2, } \\
\text { PO7 }\end{array}$ \\
\hline $\begin{array}{l}\mathrm{CO} 2 \text { : Analyse the requirements and } \\
\text { prepare Software requirement } \\
\text { specifications (SRS) document as } \\
\text { per IEEE format in line with the } \\
\text { problem defined. }\end{array}$ & $\begin{array}{l}\text { PO1, PO2, } \\
\text { PO7 }\end{array}$ \\
\hline $\begin{array}{l}\text { CO3: Create models that are } \\
\text { consistent with the requirements } \\
\text { specified in the SRS. }\end{array}$ & $\begin{array}{l}\text { PO3, PO7, } \\
\text { PO9 }\end{array}$ \\
\hline $\begin{array}{l}\text { CO4: Develop the solution by } \\
\text { applying appropriate techniques, } \\
\text { software engineering and } \\
\text { management principles and modern } \\
\text { tools to meet the requirements either } \\
\text { as an individual or by involving in } \\
\text { the team. }\end{array}$ & $\begin{array}{l}\text { PO3,PO5, } \\
\text { PO7,PO9, } \\
\text { PO11 }\end{array}$ \\
\hline $\begin{array}{l}\text { CO5: Verify \& validate the data and } \\
\text { results to arrive at valid conclusions } \\
\text { and communicate the work done } \\
\text { effectively in terms of presentations, } \\
\text { writing reports and research article } \\
\text { as per the format is given. }\end{array}$ & $\begin{array}{l}\text { PO4, PO7, } \\
\text { PO9 }\end{array}$ \\
\hline $\begin{array}{l}\text { CO6: Follow ethical principles in } \\
\text { all stage s of project work by } \\
\text { avoiding plagiarism. }\end{array}$ & PO6 \\
\hline $\begin{array}{l}\text { CO7: Articulate the impact of IT } \\
\text { solutions developed in the project } \\
\text { work with respect to societal, } \\
\text { environmental and industrial issues } \\
\text { at large. }\end{array}$ & $\begin{array}{l}\text { PO10, } \\
\text { PO12 }\end{array}$ \\
\hline
\end{tabular}


building several engineering skills in MCA graduates. This course has been set with 7 goals mapping to all Pos.

Essentially this course needs Rubrics-based assessment/evaluation. Students carry out a project work largely in Industry in different domains under the guidance of a faculty member and industry expert(s). In general, every guide feels his student project as the best one and all students expect equal marks as a team member. But they might not have contributed/ acquired skills equally. Hence it is necessary to use the rubrics for evaluation. Rubrics will be useful even to identify the best projects. As an evaluator, it is necessary to set benchmarks for our evaluation [8].

\section{Internship as a VAC}

The Internship helps in getting better exposure to the Professional learning experience, COs defined for Internships may map on to both domain-dependent and independent skills of program outcomes. Internship in vacation period (summer/winter breaks) motivates students to focus more. An internship may be of different complexity and domain. It is always not necessary to do an engineering internship; it can also be just societal or environment concerned. Students may be encouraged to do an internship in some NGOs also. Generally, an internship of 600 hours is appreciated. The internship is evaluated through reports and seminars. To improve the quality of the internship, it is recommended to take feedback on student internship.

\section{E. Case study as a value add on}

Case study plan is shown in the Table 5 where case studies identified are mentioned along with objectives, and internal tests to which learners have to get prepared. Each case study may be given a source of information availability (web link/ paper reference). Each case study may be considered as a compulsory question with $20 \%$ weightage.

Table 5: Case study plan as a value addition

\begin{tabular}{|l|l|l|l|}
\hline $\begin{array}{l}\text { Course } \\
\text { Code }\end{array}$ & 17MCA24 & Program & MCA \\
\hline $\begin{array}{l}\text { Course } \\
\text { Title }\end{array}$ & $\begin{array}{l}\text { Operating } \\
\text { Systems }\end{array}$ & Semester & 2nd \\
\hline $\begin{array}{l}\text { Faculty } \\
\text { Name }\end{array}$ & ABC & Academic Year & 2017-18 \\
\hline
\end{tabular}

\begin{tabular}{|c|c|c|c|}
\hline Sl.No. & Title & Objective & Test No. \\
\hline 1 & $\begin{array}{l}\text { A Case study } \\
\text { of process } \\
\text { management } \\
\text { in Linux }\end{array}$ & $\begin{array}{l}\text { Implementation } \\
\text { of process } \\
\text { creation and } \\
\text { management }\end{array}$ & 1 \\
\hline 2 & $\begin{array}{l}\text { The Amoeba } \\
\text { distributed } \\
\text { OS }\end{array}$ & $\begin{array}{l}\text { Key features } \\
\text { and Design of } \\
\text { OS for } \\
\text { distributed } \\
\text { systems }\end{array}$ & 1 \\
\hline 3 & $\begin{array}{l}\text { A Small } \\
\text { Memory } \\
\text { RTOS, } \\
\text { EMERALDS }\end{array}$ & $\begin{array}{l}\text { Motivation } \\
\text { Overview of } \\
\text { EMERALDS } \\
\text { Minimizing } \\
\text { Code Size } \\
\text { Minimizing } \\
\text { Execution } \\
\text { Overheads } \\
\end{array}$ & 2 \\
\hline 4 & $\begin{array}{l}\text { Mobile } \\
\text { Applications } \\
\text { Development } \\
\text { in Nigeria }\end{array}$ & $\begin{array}{l}\text { To explore the } \\
\text { Mobile Internet } \\
\text { Value Chain }\end{array}$ & 2 \\
\hline 5 & $\begin{array}{l}\text { Security } \\
\text { Enhanced } \\
\text { Linux } \\
\text { (SELinux) }\end{array}$ & $\begin{array}{l}\text { Latest Security } \\
\text { features in } \\
\text { Linux OS \& Its } \\
\text { comparison with } \\
\text { windows }\end{array}$ & 3 \\
\hline 6 & $\begin{array}{l}\text { Android OS } \\
\text { security }\end{array}$ & $\begin{array}{l}\text { To explore } \\
\text { mobile } \\
\text { application } \\
\text { security issues }\end{array}$ & 3 \\
\hline
\end{tabular}

Table-6 given below shows the Case study question asked in the internal test. In this case, $40 \%$ of the marks are allocated to innovative and case study questions.

Table 6: Case Study Question in operating system course internal test

\begin{tabular}{|c|c|}
\hline Example Question & $\begin{array}{l}\mathrm{CO}, \\
\mathrm{K}-\text { Level }\end{array}$ \\
\hline $\begin{array}{l}\text { Case Study Question: For the case of } \\
\text { EMERALD OS, analyse Process } \\
\text { Management and Memory } \\
\text { management components. Compare } \\
\text { them with the Linux Operating } \\
\text { System. If EMERALD OS to be } \\
\text { embedded in handheld device where } \\
\text { memory is a constraint, then which } \\
\text { OS architecture will you suggest and } \\
\text { why? }\end{array}$ & $\begin{array}{l}\mathrm{CO} 6, \mathrm{~K} 4 \\
\mathrm{CO} 3, \mathrm{~K} 4\end{array}$ \\
\hline
\end{tabular}


COs : Students will be able to

1. Apply the fundamental concepts of the operating systems (OS) for a given problem and discuss its performance issues.

2. Apply graph theory concepts to model OS problem and give valid conclusions.

3. Analyse the given problem and solve using OS management techniques.

4. For the given case study of the operating system, apply the concepts of networking, file systems, protection and computer security and analyse its design principles.

5. Design algorithms for the given problem \& compare its performance with existing ones

6. Identify the scenario of Real-time OS in the industry and write a report on the design of process/ task management, security, and protection.

\section{K1: Remember, K2: Understand K3:Apply \\ K4:Analyse K5: Evaluate $\quad$ K6: Create}

\section{F. Certification Courses as Value ad-on}

It is necessary to ensure that students stay abreast of the latest industry standards. To achieve this purpose it is required to impart professional knowledge with relevant certifications to increase their employability. Example certifications are Information Security ISO 27001, AWS Certified Cloud Practitioner, and Risk Assessment: ISO 31000 , Product Management, Power BI and DevOps. If feasible certification courses may be introduced as a part of the program structure.

\section{Check List for a Course Plan}

Once a detailed OBE TLP plan is ready, a checklist as shown in Table-7 can be prepared and maintained in Course File [2].

\section{Curriculum gap analysis}

Any given curriculum if it does not contribute to at least one PO, then it can be claimed that there exists a curriculum gap. This curriculum gap can be addressed
Table 7: Readiness of Lesson Plan for the academic year 2017-18 [odd]

\begin{tabular}{|c|c|c|c|}
\hline $\begin{array}{l}\text { S1. } \\
\text { No. }\end{array}$ & $\begin{array}{l}\text { Teaching / Learning } \\
\text { Methods }\end{array}$ & $\begin{array}{l}\text { Module } \\
\text { / Topic }\end{array}$ & $\begin{array}{l}\text { Yes } \\
/ \mathrm{No}\end{array}$ \\
\hline 1 & $\begin{array}{l}\text { Title of Innovative Teaching } \\
\text { Method [ITM] }\end{array}$ & & \\
\hline 2 & $\begin{array}{l}\text { Title of Cooperative } \\
\text { Teaching / Learning Method } \\
{[\text { CLM }]}\end{array}$ & & \\
\hline 3 & PDC by Industry Experts & & \\
\hline 4 & $\begin{array}{l}\text { Project Based Learning } \\
\text { [PBL] }\end{array}$ & & \\
\hline 5 & $\begin{array}{l}\text { Problem Based Learning } \\
\text { [PRBL] }\end{array}$ & & \\
\hline 6 & Open Ended Question & & \\
\hline 7 & $\begin{array}{l}\text { Virtual Labs as applicable to } \\
\text { the Course }\end{array}$ & & \\
\hline 8 & $\begin{array}{l}\text { Case Study Questions in } \\
\text { Specific Format }\end{array}$ & & \\
\hline 9 & $\begin{array}{l}\text { Simulation Software as } \\
\text { applicable to the Course (C) }\end{array}$ & & \\
\hline 10 & $\begin{array}{l}\text { Digital space Material } \\
\text { Upload [Lecture Notes, } \\
\text { Case Studies, MOOC / } \\
\text { NPTEL based assignments] } \\
\text { (C) }\end{array}$ & & \\
\hline 11 & $\begin{array}{l}\text { Tutorial / Remedial Classes } \\
\text { as applicable }\end{array}$ & & \\
\hline 12 & $\begin{array}{l}\text { Tools Introduced Beyond } \\
\text { Syllabus }\end{array}$ & & \\
\hline 13 & $\begin{array}{l}\text { Specific Strategy to get } \\
100 \% \text { POs }\end{array}$ & & \\
\hline 14 & URLs [Beyond Syllabus] & & \\
\hline 15 & $\begin{array}{l}\text { Assignment K4 / K5 / K6 } \\
\text { level }\end{array}$ & & \\
\hline 16 & $\begin{array}{l}\text { Modification to lab } \\
\text { programs }\end{array}$ & & \\
\hline 17 & $\begin{array}{l}\text { Educational Videos as } \\
\text { applicable to the Course }\end{array}$ & & \\
\hline 18 & Any others Please Specify & & \\
\hline
\end{tabular}

Course Coordinator Signature with date

by offering a VAC. On the other hand, given the appropriate curriculum, if course coordinator does not have set the proper goals which are specific, measurable, attainable within the specific time period, then there may exist gap and hence outcomes may not be achievable. Another possibility is learner engagement if not up to the expected level, and then also CO-PO attainment may not happen. In higher 
education focus on PO1-PO3 is not sufficient, higher cognitive levels, as well as all POs attainment, are necessary. It may be noted that teacher/students if the focus on understanding/ remembering skills, it is not useful for professional courses. PO starts with apply skill, COs should focus on multiple feasible skills, project-based learning, open short term course with the mini project, internship as a course, skill development workshops as a course can map to higher cognitive levels. In a non-autonomous system, when given the syllabus is not sufficient to attain all POs, to ensure PO attainment it is recommended to adopt VAP. In order to achieve PO attainment at the expected level, assuming the content of the syllabus is well designed, if the course coordinator does not set higher cognitive goals, then all POs may not be having mapping. Further, VAP with higher cognitive skills enhances the contributions to POs.

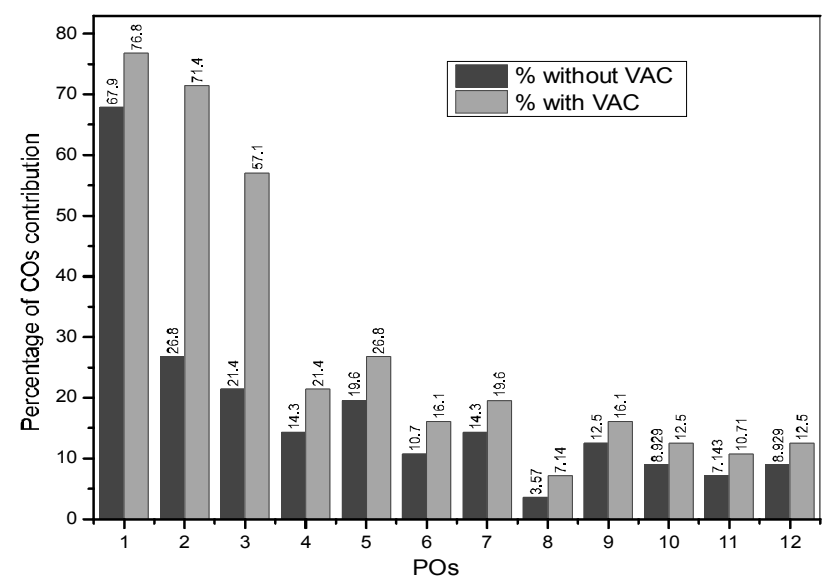

Fig. 3: Comparison of Cos contributions to POs

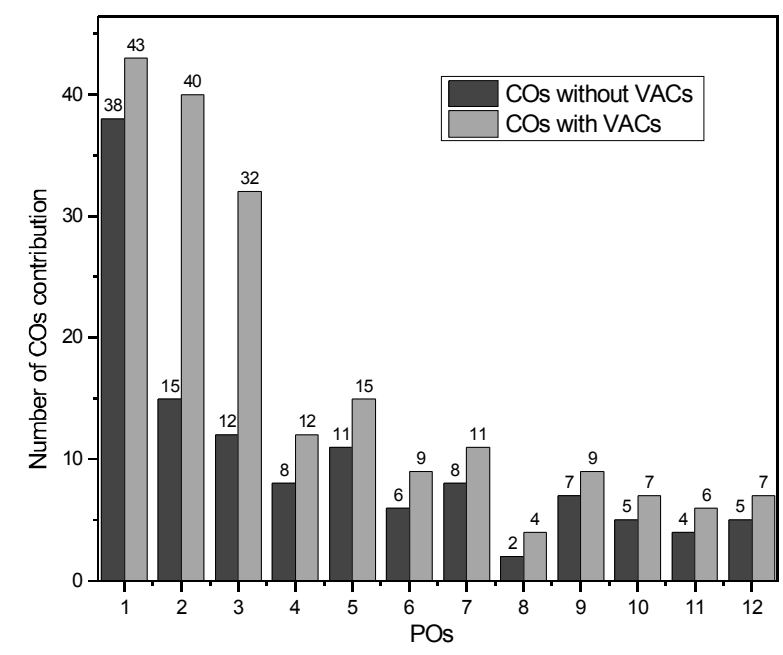

Fig. 4 : CO contributions are moderate with moderate Cos
All course outcomes defined for theory/ practical and project courses are mapped to POs. The COs contributions without VACs for the Scheme and Syllabus of 2018-21 in the academic year 2018-19 is shown in Figure-3. It can be noted that no. of courses contributing to $\mathrm{PO}$ attainment may be strengthened by defining 5 to 6-COs of different cognitive levels for a course of 40-50 hour syllabus. Further by adding VACs, PO mapping can be improved as shown in Figure-3. It implies that defining COs of higher cognitive level mapping to the optimal number of POs in case of regular theory/practical courses and VACs strengthens the POs attainment.

\section{Sample analysis of skills acquired in theory courses.}

Method of analysis:- The right data collection method is one of the major steps to provide proper insights and can avoid time-wasting misdirection. In our case, the method of data collection is quantitative, where the sampling method is the mixture of random sampling for the course selection and followed by cluster sampling for the CO-PO mapping. In random sampling, all the core subjects of the program were considered and elective subjects were considered for analysis only if those electives were opted by more than $70 \%$ of students. All the data obtained was the primary data, except in a few cases where the other teachers taught those subjects whose secondary data was drawn from the department documents. All the secondary data collected were checked and verified before considered for the analysis.

Analysis of 310 students samples data was collected which spread across three years from August 2013 to November 2017 who participated in the learning of eight theory courses. For the analysis, the target level set was $70 \%$ and above. During this duration, $51.38 \%, 59.16 \%$, and $24.44 \%$ of students have achieved in the apply, analyze, and create/design levels of the set target respectively. Table- 8 indicates

Table 8 : Analysis of skills acquired in 8 different theory courses

\begin{tabular}{|c|c|c|c|c|c|c|c|c|c|}
\hline \multirow[b]{2}{*}{ SI No. } & \multirow[b]{2}{*}{ Course Title } & \multirow[b]{2}{*}{ Period } & \multirow{2}{*}{\begin{tabular}{|l} 
Total No \\
of \\
students
\end{tabular}} & \multicolumn{6}{|c|}{ C01- Apply level $>=70 \%$ CO2 - Analyse Level $=70 \%$ CO3 - Design Level > $=70 \%$} \\
\hline & & & & \begin{tabular}{|c|c}
$\begin{array}{c}\text { No. of } \\
\text { students }\end{array}$ \\
students
\end{tabular} & $\%$ & $\begin{array}{c}\begin{array}{c}\text { No. of } \\
\text { students }\end{array} \\
\end{array}$ & $\%$ & $\begin{array}{c}\text { No. of } \\
\text { students }\end{array}$ & $\%$ \\
\hline 1 & Operating System & Feb-2014 to July-2014 & 41 & 38 & 93 & 0 & 0 & 0 & 0 \\
\hline 2 & Java programming & Aug-2015 to Nov-2015 & 46 & 28 & 65 & 35 & 75 & 0 & 0 \\
\hline 3 & System Simulation & Aug-2015 to Nov-2015 & 40 & 7 & 17 & 34 & 86 & 0 & 0 \\
\hline 4 & Data structure using $\mathrm{C}$ & Aug 2016 to Dec 2016 & 53 & 43 & 81 & 38 & 73 & 23 & 49 \\
\hline 5 & Computer organisation & Sep-2016 to Dec-2016 & 53 & 0 & 0 & 24 & 45 & 0 & 0 \\
\hline 6 & Cryptograhy & Feb-2017 to May-2017 & 22 & 20 & 90 & 20 & 90 & 20 & 90 \\
\hline 7 & Operating System & Feb-2017 to May-2017 & 31 & 23 & 74 & 15 & 50 & 0 & 0 \\
\hline 8 & Intellectual Property Rights & Sep-2017 to Noy-2017 & 24 & 3 & 13 & 22 & 90 & 0 & 0 \\
\hline
\end{tabular}


Table 9:Segregation of learners at different levels

\begin{tabular}{|c|l|l|}
\hline \multicolumn{3}{|c|}{ August 2013 to November-2017 } \\
\hline Sl.No. & Total students & 310 \\
\hline 1 & CO1 at Apply level & 185 \\
\hline 2 & CO2 at Analyse Level & 213 \\
\hline 3 & CO3 at Design Level & 88 \\
\hline
\end{tabular}

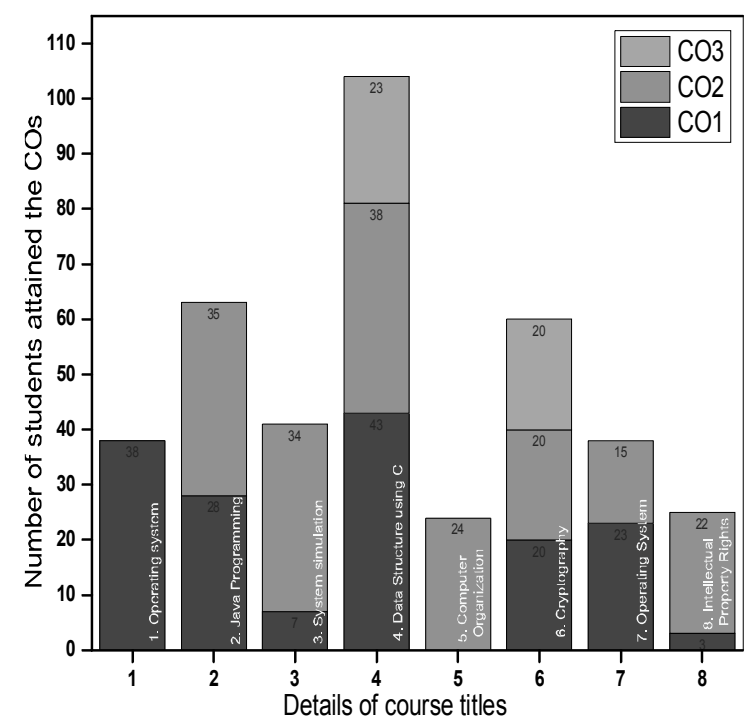

Fig. 5: Number of students attained Cos in 8 theory courses

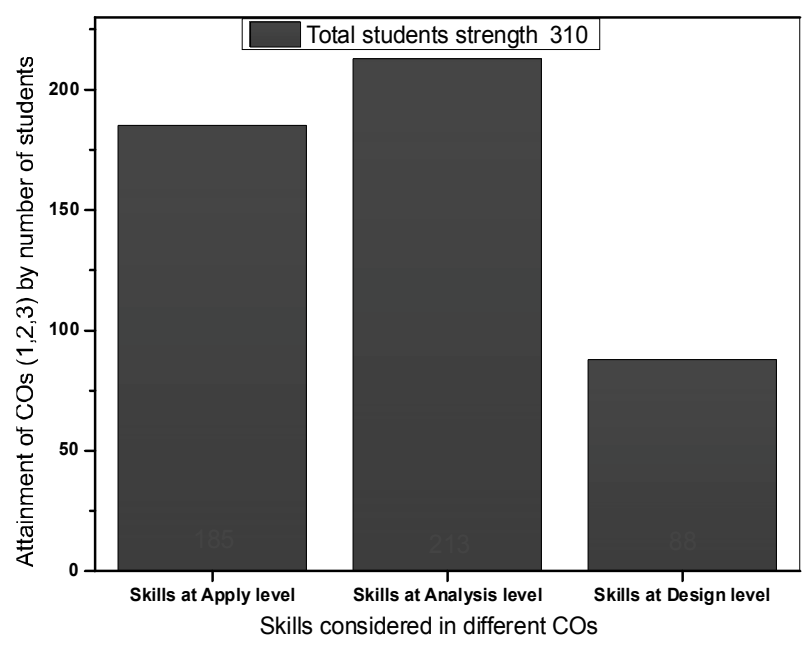

Fig. 6: Graph showing seggreagtion of learners at apply,analyse and design level

the data collected for the analysis. It was found that these courses were only theoretical based having lack of design skills. Therefore, it is necessary to implement more skills which are on design oriented.

\section{Analysis of PO attainment considering VACs}

Program outcomes of three batches namely 201215, 2013-16, and 2014-17 of the MCA program were analyzed. In each batch, there were 25 theory courses, 15 laboratory courses, and 6th-semester project work. Total data of 737 students from the academic year 2012-13 to 2016-2017 were considered. The no. of students in 2012-13, 2013-14, 2014-15, 2015-16 and 2016-17 were respectively as follows: $166,154,128$, 154 and 135. In addition to regular courses, VACs namely Seminars, Case-Studies, PBL and IE-OSC were considered for the analysis. It is found that overall PO attainment was improved due to proper course goals defined and in line with the goals teaching-learning processes were conducted. As iterated several times VACs adopted enhanced the PO attainment as indicated in the tables below.

Correlation between course, outcome and program outcome is defined as follows. If $60 \%$ and above of the students have scored $70 \%$ and above marks then the correlation is the high level which is indicated by a numerical value 3 . If $55 \%$ to $59 \%$ of the students have scored $70 \%$ and above marks then the correlation is said to be at a moderate level which is indicated by value 2 . If $50 \%$ to $54 \%$ of students have scored $70 \%$ and above marks then the correlation is low which is represented by a numerical value 1 . PO attainment is calculated by taking $60 \%$ of the direct assessment and $40 \%$ of the indirect assessment.

Table 10 : PO attainment for the batch 2012-15

\begin{tabular}{|l|c|c|c|c|c|c|c|c|c|c|c|c|}
\hline Attainment & PO1 & PO2 & PO3 & PO4 & PO5 & PO6 & PO7 & PO8 & PO9 & PO10 & PO11 & PO12 \\
\hline $\begin{array}{l}60 \% \text { of Direct } \\
\text { Assessment }\end{array}$ & 1.28 & 1.22 & 1.23 & 0.82 & 1.50 & 1.23 & 1.26 & 0.95 & 1.27 & 0.94 & 0.72 & 0.62 \\
\hline $\begin{array}{l}40 \% \text { of } \\
\text { Indirect } \\
\text { Assessment }\end{array}$ & 1.2 & 1.2 & 1.2 & 1.2 & 1.2 & 1.2 & 1.2 & 1.2 & 1.2 & 0 & 0 & 0 \\
\hline $\begin{array}{l}\text { Final PO } \\
\text { attainment }\end{array}$ & 2.48 & 2.42 & 2.43 & 2.02 & 2.70 & 2.43 & 2.46 & 2.15 & 2.47 & 0.94 & 0.72 & 0.62 \\
\hline
\end{tabular}

Table 11 : PO attainment for the batch 2013-16

\begin{tabular}{|l|c|c|c|c|c|c|c|c|c|c|c|c|}
\hline \multicolumn{1}{|c|}{ Attainment } & P01 & P02 & P03 & P04 & P05 & P06 & P07 & P08 & P09 & P010 & P011 & P012 \\
\hline $\begin{array}{l}\text { 60\% of Direct } \\
\text { Assessment }\end{array}$ & 1.28 & 1.25 & 1.25 & 1.13 & 1.22 & 1.23 & 1.06 & 0.95 & 1.28 & 0.94 & 0.72 & 0.62 \\
\hline $\begin{array}{l}40 \% \text { of } \\
\text { Indirect } \\
\text { Assessment }\end{array}$ & 1.2 & 1.2 & 1.2 & 1.2 & 1 & 1.2 & 1.2 & 0.8 & 1.2 & 0 & 0 & 0 \\
\hline $\begin{array}{l}\text { Final PO } \\
\text { attainment }\end{array}$ & 2.48 & 2.45 & 2.45 & 2.33 & 2.22 & 2.43 & 2.26 & 1.75 & 2.48 & 0.94 & 0.72 & 0.62 \\
\hline
\end{tabular}

Table 12 : PO attainment for the batch 2014-17

\begin{tabular}{|l|c|c|c|c|c|c|c|c|c|c|c|c|}
\hline \multicolumn{1}{|c|}{ Aftainment } & P01 & P02 & P03 & P04 & P05 & P06 & P07 & P08 & P09 & P010 & P011 & P012 \\
\hline $\begin{array}{l}\text { 60\% of Direct } \\
\text { Assessment }\end{array}$ & 1.28 & 0.70 & 1.21 & 1.15 & 1.17 & 1.22 & 1.26 & 0.95 & 1.27 & 0.96 & 1.03 & 0.91 \\
\hline $\begin{array}{l}40 \% \text { of } \\
\text { Indirect } \\
\text { Assessment }\end{array}$ & 1 & 1 & 1 & 1 & 1 & 1.2 & 1 & 1 & 1.2 & 0 & 0 & 0 \\
\hline $\begin{array}{l}\text { Final P0 } \\
\text { attainment }\end{array}$ & 2.28 & 1.70 & 2.21 & 2.15 & 2.17 & 2.42 & 2.26 & 1.95 & 2.47 & 0.96 & 1.03 & 0.91 \\
\hline
\end{tabular}




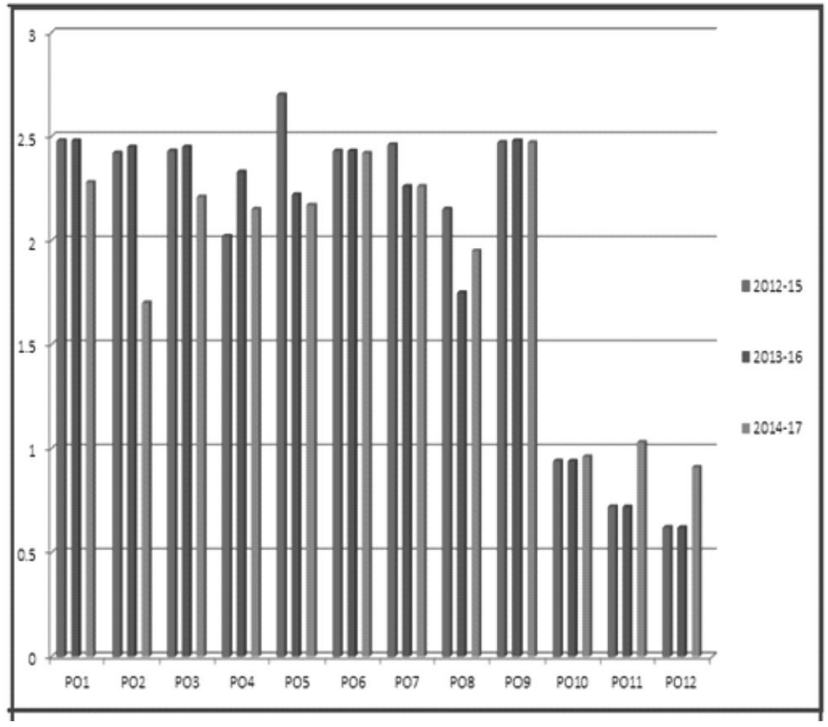

Fig. 7: Graph showing imorvements in PO attainment due to VACs, PBL,Case study etc

In other words, when the VACs are adopted with typical COs, and direct assessments were taken, $\mathrm{CO}$ attainments were computed and mapped to appropriate POs, then the process enabled the attainment of program outcomes as shown above. It can be noted that in 2014-17 there is a significant improvement from 0.94 to $0.96,0.72$ to 1.03 and 0.6 to 0.91 in PO10 (societal and environmental concern), PO11(individual and teamwork), PO12 (innovation and Entrepreneurship) respectively. During the analysis, it is found that PO attainment was able to achieve during the year 2014-2017 when compared to the previous two batches.

\section{Conclusion}

In this paper, OBE curriculum design, best practices such as partial delivery of classes by industry experts, and best-practiced VACs are introduced, a framework of IE-VAC design is presented, and course plans of different VACs/value add-ons are explained. Different formats designed help beginners to start implementing the OBE process and further gives an opportunity for experts to improve continuously. If adopted effectively VACs can reduce the curriculum gap, usage of ICT in TLP can further make OBE more meaningful and effective. The dept. of MCA, BMSIT\&M, Bangalore has practiced several best practices and implemented VACs with OBE orientation which has improved POs attainment through course outcomes. The proposed VACs, value add-ons, framework, and different plans shall continuously evolve based on feedback and suggestions from various stakeholders.
Defining the COs with higher-order cognitive levels for regular theory, laboratory, VACs, projectbased learning, case study, seminar, industry internship/project, technical competitions, implementing TLP strategies, taking the assessment, performing evaluation improves program outcomes attainment.

There are a total of 40 theory/practical courses and a project course in the MCA syllabus. By adding VACs namely PBL, CBL, Seminar, IE-OSC, Internship/ industrial visit, PDC by industry experts and open-ended assignments, Technical competitions for programs in Tier-II institutions can add 9-10 additional courses. The COs of VACs were defined after the curriculum gap analysis. Therefore, VACs can contribute to the enhancement of PO attainment by twenty percent. Further,5-6 COs of each course that can be mapped to different POs also improves PO attainment. It should be noted that in a semester scheme, it is challenging to implement VACs without burdening the students but engaging them in effective learning.

An outcomes-based education needs to adopt best practices, VACs that are customized and information communication technology as a tool to enhance the learning experience and move towards optimal attainment through learning outcomes. In this paper, different best practices that add values are narrated. Examples given may be adopted in different programs so that OBE curriculum design, assessment, and instructional strategies will become further effective. While designing the OBE curriculum these $\mathrm{VACs} / \mathrm{schemes}$ may be considered as a part of the learning. It is the innovative strategies that can boost the successful implementation of OBE which keeps TLP evolving. It shall be noted that the evolution of OBE TLP is a continuous process.

\section{Acknowledgement:}

Author, Dr. Arun Kumar B.R. is thankful for the encouragement and support extended by the dept. of computer Applications and BMSIT\&M Principal and Management in carrying out this research work.

\section{References}

[1] Arunkumar B. R (2015). The relevance of Bhagavad Gita to NBA graduate attributes, International Journal of Research in 
Management \& Social Science, 3(3), 2322 0899.

[2] Arun Kumar B. R (2017). Outcomes Based Education (OBE) Teaching-Learning plan: A Case study of Operating System Course, International Journal of Multidisciplinary Educational Research (IJMER), 6(4), 182-194.

[3] Arun Kumar B.R (2019). Defining course outcomes, designing OBE Question paper and scrutinizing to align question paper with targeted Cos, International Journal of Multidisciplinary Educational research, 1(2)), 79-88.

[4] Arun Kumar B.R (2018). How to enable and motivate slow and fast learners for fostering the attainment of Programme outcomes in Outcome Based Education, International Journal of Multidisciplinary Educational Research, 7 (12),188-196.

[5] Abidin, Z., Anuar, A., Shuaib, N. H. (2009). Assessing the attainment of course outcomes (co) for an engineering course. Proceedings of the 2nd ICTL, Malaysia, 1-7.

[6] Anderson, L. W., Krathwohl, D. R. (Eds.). (2001). A taxonomy for learning, teaching, and assessing: A revision of bloom's taxonomy of educational objectives. Allyn \& Bacon. Boston, MAPearson Education Group.

[7] Basri, N. E. A., Taib, K. A., Jaafar, O., Zain, S. M., Suja, F., Kasa, A., Shanmugam, N. E. (2010). An evaluation of programme educational objectives and programme outcomes for civil engineering programmes. Procedia Social and Behavioral Sciences, 18, 56-64.

[8] Bhagyalaksmi, H. R., Seshachalam, D., Lalitha, S. (2015). Program outcome attainment through course outcome: A comprehensive approach. In Natrajan, R. (Ed.), Proceedings of the international conference on transformations in engineering education, Springer, 279-287.

[9] Biney, P., Bryant, M. R. (2005). A novel strategy for the direct assessment and improvement of engineering programs developed and implemented by Prairie View A\&M University. Paper presented at ASEE conference, Portland,
[10] Retrieved from https://peer.asee.org/a-novelstrategy-for-the-direct-assessment-andimprovement-of-engineering-programsdeveloped-and-implemented-by-prairie-view-am-university.

[11] Bloom, B., Engelhart, M., Furst, E., Hill, W., Krathwohl, D. (1956). Taxonomy of educational objectives: The classification of educational goals. Handbook I: Cognitive domain. New York, NY: Longmans.

[12] Dalton, E. (2003). The "new bloom's taxonomy," objectives and assessments. Retrieved from http://gaeacoop.org/dalton/publications/new_bl oom.pdf

[13] Drakshayani, D. N. (2016). A preliminary study on Attainment of course outcomes for outcome based education in mechanical engineering using a case study of material science and metallurgy. IOSR Journal of Research \& Method in Education, 6, 76-83.

[14] Elaine H.J.Yew, Karen Goh ((2016). ProblemBased Learning: An Overview of its Process and Impact on Learning, Health Professions E d u c a t i o n , 2 $75-79$. https://doi.org/10.1016/j.hpe.2016.01.004

[15] Gurocak, H. (2008). Direct measures for course outcomes assessment for ABET accreditation. Paper presented at American Society Engineering Education, Pittsburgh, PA.

[16] Haolader, F. A., Ali, R. M., Foysol, K. M. (2015). The taxonomy for learning, teaching and assessing: Current practices at polytechnics in Bangladesh and its effects in developing students. Competences International Journal for Research in Vocational Education and Training, 2,99-118.

[17] Houshangi, N. (2003). Curriculum assessment and enhancement at Purdue University Calumet based on ABET 2000. Paper presented at American Society for Engineering Education, $\mathrm{Ham}$ mond, IN. Retrieved from http://ilin.asee.org/doc/Paper3B1.pdf

[18] Lynn Meek Ulrich Teichler Mary-Louise Kearney (eds.) (2010) Higher Education, Research and Innovation: Changing Dynamics 
Report on the UNESCO Forum on Higher Education, Research and Knowledge 20012009.

[19] Masni-Azian, A., Rahimah, A. H., Othman, M. S. (2014). Towards OBE: A case study of course outcome (CO) and programme outcome (PO) attainment for product design and development course. IOSR Journal of Research \& Method in Education, 4, 55-61.

[20] Massa, L. J., Kasimatis, M. (2017). Meaningful and manageable program assessment: A how-to guide for higher education faculty. Sterling, VA: Stylus Publishing.

[21] Memon, Q. A., Harb, A. (2009). Developing electrical engineering education program assessment process at UAE University. Australian Journal of Engineering Education, 15, 155-164.

[22] Madhuri Mavinkurve (2016). Development and Assessment of Engineering Design Competencies using Technology-EnhancedLearning environment, Inter-Disciplinary Program in Educational Technology, IIT,Bombay.

[23] Palomba, C., Banta, T. (1999). The essentials of successful assessment. In Palomba, C. A., Banta, T. W. (Eds.), Assessment essentials: Planning, implementing, and improving assessment in higher education. San Francisco, CA: JosseyBass, 85-114.

[24] PK Tulsi and MP Poonia (2015). Expectations of Industry from Technical Graduates: Implications for Curriculum and Instructional Processes, , Journal of Engineering Education Transformations, Special Issue: Jan., eISSN 2394-1707,page.no.,19-24.

[25] Ramchandra, S., Maitra, S., MallikarjunaBabu, M. (2014). Method for estimation of attainment of program outcome through course outcome for outcome based education. Paper presented at IEEE International Conference on MOOC, Innovation and Technology in Education (MITE). https://ieeexplore.ieee.org/document/ 7020231
[26] Ranganath, R. V. (2016). Some examples for CO-PO mapping and corresponding assessments. http://www.nbaind.org/files/Somemore-examples-on-attainment-of-COs-and-PO21-may-2016.pdf

[27] Rao, N. J. (2015). Outcome based education. http://textofvideo.nptel.ac.in/127108005/lec4.p df

[28] Sahasrabudhe, A. (2015). Outcome based education and NBA accreditation. Retrieved from http://www.nbaind.org/files/obe-and-nbaaccreditation.pdf

[29] Shaeiwitz, J., Briedis, D. (2007, June 24-27). Direct assessment measures. Paper presented at American Society of Engineering Education, Honolulu, HI.

[30] Shane, H. G. (1981). Significant writings that have influenced the curriculum. Phi Delta Kappan, 62, 311-314.

[31] Soragaon, B., Mahesh, K. S. (2016). Measuring attainment of course outcomes and program outcomes-A simplified approach as per selfassessment report-June 2015. IOSR Journal of Research \& Method in Education, 6, 13-18.

[32] Spady, W. G. (1994). Outcome-based education: Critical issues and answers. Arlington, VA: American Association of School Administrators.

[33] Suskie, L. (2004). Assessing student learning: A common sense guide. Bolton, MA: Anker Publishing.

[34] Turkmen, N., Khaled, A. R. A., Al-Raghbi, O. M., Zaki, G., Siddique, M., Gari, A., Bokhary, A. (2010). Procedure to assess engineering courses based on program outcomes. Retrieved from https://www.researchgate.net/publication/27196 2976_A_Procedure_to_Assess_Engineering_C ourses_Based_on_Program_Outcomes

[35] Tamim, S. R., \& Grant, M. M. (2013). Definitions and Uses: Case Study of Teachers Implementing Project-based Learning. Interdisciplinary Journal of Problem-Based Learning, 7 (2). Avai 1 ab 1 e a t: https://doi.org/10.7771/1541-5015.1323. 
[36] Viswanadha, R. S. (2016). Outcome based education. Retrieved from https://www. youtube.com/watch? $v=$ aitqARyQkRQ

[37]Wahab, H. F. A., Ayob, A., Zaki, W. M. D. W., Hussain, H., Hussain, A., Mokri, S. S. (2011). Program outcomes measurement and assessment processes. Procedia Social and Behavioral
Sciences, 18, 49-55.

[38]Wang Lixun (2011). Designing and Implementing outcome-based learning in a Linguistic course: A case study of Hong Kong, Procedia Social and Behavioural Sciences, 12, 918.https://doi.org/10.1016/j.sbspro.2011.02. 004 